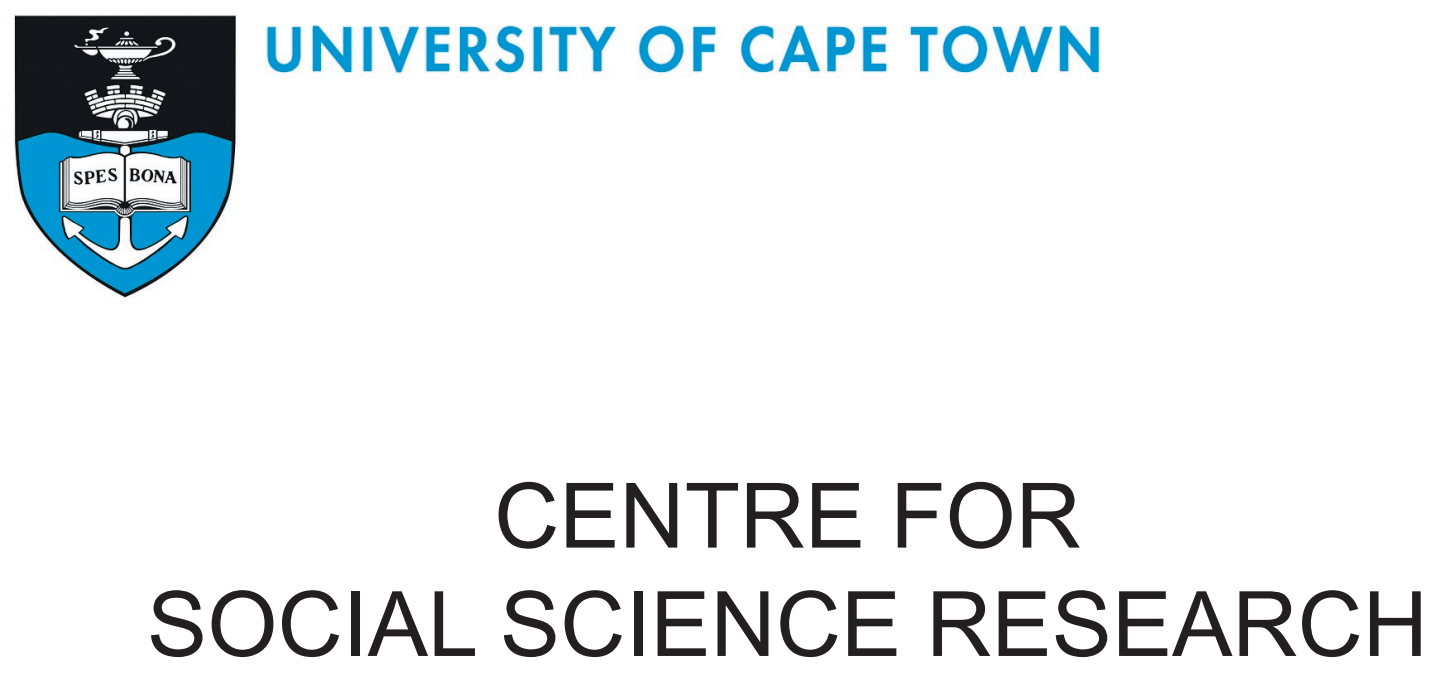

\title{
THE MUTABILITY OF DISTRIBUTIVE JUSTICE ATTITUDES IN SOUTH AFRICA
}

Jeremy Seekings

CSSR Working Paper No. 125

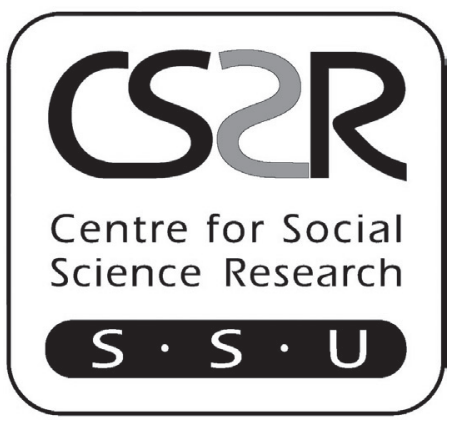


Published by the Centre for Social Science Research University of Cape Town

2005

Copies of this publication may be obtained from:

\author{
The Administrative Officer \\ Centre for Social Science Research \\ University of Cape Town \\ Private Bag \\ Rondebosch, 7701 \\ Tel: (021) 6504656 \\ Fax: (021) 6504657 \\ Email: kforbes@cssr.uct.ac.za
}

Price in Southern Africa (incl. VAT and postage): R 5.00

or it can be downloaded from our website http://www.cssr.uct.ac.za/index.html

ISBN 1-7701 1-058-5

(c) Centre for Social Science Research, UCT, 2005 


\title{
CENTRE FOR \\ SOCIAL SCIENCE RESEARCH
}

\author{
Social Surveys Unit
}

\section{THE MUTABILITY OF DISTRIBUTIVE JUSTICE ATTITUDES IN SOUTH AFRICA}

Jeremy Seekings

CSSR Working Paper No. 125 
Jeremy Seekings is Professor of Political Studies and Sociology at the University of Cape Town (UCT), and Director of the Social Surveys Unit within the Centre for Social Science Research (CSSR). 


\section{The Mutability of Distributive Justice Attitudes in South Africa}

\section{Abstract}

Even after ten years of democratic government, South Africa remains an unusually unequal society. Inequalities in the distribution of incomes both reflect and reproduce inequalities of opportunity. Yet curiously little research has been conducted on what South Africans think about inequality, and their views on distributive justice. The limited extant research suggests that most South Africans believe that their country is too unequal, that there is strong support for government action to reduce inequalities, and that class consciousness and racial identities are both widespread. This paper uses existing and new data to show that distributive justice perceptions and attitudes in South Africa are mutable: perceptions and attitudes change according to the precise question posed, have changed over time, and change in the face of counter-arguments. South Africans, like people in many other parts of the world, see some poor people as more deserving than others, with perceived desert reflecting recognised needs (e.g. the elderly), responsibilities (e.g. breadwinners) and behaviour (with respondents being hostile to support for chronic drinkers, for example). Some, but not most, South Africans also become less supportive of the government supporting the poor if taxes are to be increased. Overall, South Africans seem to recognise a wide range of deserving poor, and even richer elites are inclined toward generosity, but support for redistribution is far from unconditional.

\section{Introduction}

Internationally, the study of attitudes towards distributive justice is a rich and fast-growing field. As is generally the case, most research has been conducted in societies of North America and Western Europe, which are societies with much lower levels of inequality than South Africa, in part due to a variety of inequality-reducing interventions by 'welfare capitalist' states (to borrow a phrase from Esping-Andersen, 1990). Despite the reduced inequality in these societies, scholars have sought to understand why there is not more demand for downward redistribution, especially in societies such as the USA where the 
capitalist element in 'welfare capitalism' appears stronger than the 'welfare' component.

Hochschild's seminal study of What's Fair? American Beliefs about Distributive Justice (1981) was based on intensive, qualitative interviews with twenty-eight working adults in New Haven. She identified four broad reasons for the muted demands for downward redistribution:

First, some people do not seek it because they do not want it. ... Most people do not seek downward redistribution because they cannot imagine it or do not believe in its possibility. ... A few do not seek redistribution because they strongly oppose it. ... A few people do not seek redistribution because they do not care one way or the other about it. ... They just want to be left alone. (ibid: 278-9)

But Hochschild also noted a range of redistributive programmes that enjoyed strong support:

Both rich and poor strongly endorse a program of guaranteed jobs. ... Secondly, both rich and poor support much more equality than they realize, as long as it is couched in terms of need, investments, or results - anything except equality per se.... [A]lmost everyone, rich and poor, is incensed that the very wealthy do not pay their fair share of taxes ... [although] no one is enthusiastic about, and very few even accept, inheritance taxes. (ibid: 279-80)

Hochschild also found that attitudes had changed since the 1950s. People were less likely than before to see poverty as a 'punishment for sin or laziness', and more likely to see it instead as 'a result of bad luck or even structural biases' (ibid: 280). Overall, however, too many people are ambivalent about redistribution, rarely opposing it but rarely demanding it with any commitment or coherence.

Among the more recent studies of popular attitudes towards poverty and inequality is Martin Gilens' Why Americans Hate Welfare (1999). Like Hochschild, Gilens found that attitudes were complex:

... Americans oppose welfare, ... hold cynical views of welfare recipients, and ... their thinking about poverty and welfare is permeated by their beliefs about blacks. But just as important is that Americans are committed to helping the poor - they donate their own time and money to charitable causes, they want their government to do more to help the poor, and they consistently express a willingness to pay higher taxes to help poor people and welfare recipients obtain 
better wages, better housing, medical care, child care, education, and job training. (Gilens, 1999: x)

Gilens' study revolves around understanding how a commitment to individualism - 'pulling yourself up by your own bootstraps' - can and does coexist with strong support for public interventions. In the USA, public interventions are supported if they are seen to help people to help themselves or to provide a cushion when individual efforts are not enough. Opposition to welfare is not due to a principled opposition, but rather the perception that most welfare recipients are undeserving. Public interventions are opposed when they appear to help the 'undeserving poor'. And - in the USA at the end of the twentieth century - perceptions of the undeserving poor are bound up with racial stereotypes. Put bluntly, many white Americans dislike welfare because it is seen as support for lazy, black people, people whose poverty is seen as being due to a lack of effort and who are therefore, as a group, undeserving. Attitudes towards welfare are far more racialised than welfare itself: only just over one-third of welfare recipients in the USA are African American (ibid: 5).

Gilens uses an extraordinary range of survey data on public opinion (including especially the 1991 National Race and Politics Study, one of a series of Berkeley-based projects directed by Paul Sniderman). These are combined with detailed studies of the racialisation of welfare in the media over several decades. Most recent studies rely only on survey data, and the explosion of research reflects in large part the ready availability of new, cross-national data-sets on public opinion (notably the International Social Justice Project - used by, for example, Osberg and Smeeding, 2004 - or the older modules on inequality included in some International Social Science Program or ISSP surveys - see Kluegel et al., 1995).

Alesina and Glaeser (2004) also point to racial diversity in explaining why there is less redistribution through the state from rich to poor in the USA than in Europe. They show that, compared to Europeans, Americans are more likely to think that the poor are lazy and could escape from poverty if they worked harder. They also cite evidence from experimental and other studies that people are more generous to members of their own racial or ethnic group than to members of other groups. But their primary evidence on the significance of racial diversity for redistribution is not attitudinal. They rely instead on analysis on the relationship between racial (or ethnic) fractionalisation and redistribution in different countries or (within the USA) different states and cities. Such comparisons consistently show that there is a negative correlation between racial diversity and redistribution. 
In contrast to the abundance of research on 'Northern' societies, there is little research on public attitudes towards redistribution in the 'South'. The obvious explanations for this are that public attitudes matter less when there is no democracy or democracy is ineffective, that there is relatively little data on public attitudes, or that it is impossible to collect meaningful attitude data. Unsurprisingly, there is more research on the attitudes towards distributive justice and redistribution among elites (see especially Reis and Moore, 2005). But all three of the obvious explanations are less compelling than they might seem. As Bratton, Mattes and Gyimah-Boadi (2004) argue strongly, democratisation has meant that public attitudes have become more consequential politically, data have become more readily available on many aspects of public opinion, and there is little evidence that survey data need be viewed with any more circumspection in the 'South' than in the 'North'. Studies of popular attitudes toward inequality are beginning to appear in Southern contexts such as Brazil (Scalon, 2004).

South Africa is one country in the South with an astonishing abundance of data on public opinion, much of which is publicly available but little of which has been analysed. Series of surveys include: the surveys in South Africa that form part of the World Values Survey (in 1981, 1990, 1995 and 2001) and Afrobarometer (in 2000, 2002 and 2004); surveys conducted by the Human Sciences Research Council (HSRC) as part of their research programme on social movements (annually between 1994 and 2000 - see Klandermans, Roefs and Olivier, 2001), their general or omnibus national surveys (annually in the late 1990s) and the recently-initiated South African Social Attitudes Survey (SASAS, in 2003 and 2004); opinion polls conducted by IDASA in the midand late 1990s; and the South African Reconciliation Barometer conducted by the Institute for Justice and Reconciliation (IJR) (in 2001 and 2003). Most of these are publicly available (but not the SASAS or IJR data). All of them include odd questions on distributional issues, and some include some very useful questions on relative deprivation, perceived justice and so on. An unknown number of other studies using broad samples has been conducted by South African political parties, but the data are not publicly available and it is difficult to access even the questionnaires.

In addition to the studies above that used broad samples (although not necessarily samples that were represented of the South African population as a whole), a range of surveys have been conducted using more limited samples but with a more direct focus on distributive issues. In 2001, the International Labour Organisation (ILO) conducted a survey in two metropolitan areas (Cape Town and Durban) as part of its People's Security Survey series. The survey examines diverse aspects of 'insecurity'. The data are not publicly available, but some results have been reported (ILO, 2004). A series of surveys conducted 
in Cape Town by the Centre for Social Science Research at the University of Cape Town have included questions on distributive justice (see Seekings, 2002a; Seekings, Alexander et al., 2004; Seekings et al., 2005).

These various data-sets constitute a considerable - but also under-utilised resource. Despite the recognition that South Africa has a very high level of income inequality, almost no research has been conducted on attitudes towards inequality in South Africa. There is slightly more research about perceptions of poverty (May and Norton, 1997; Sangoco, 1998), and this sometimes touches on inequality (e.g. Klasen, 1997). Similarly, research on expectations especially the expectations of newly-franchised black citizens after 1994 sometimes touched on distributional issues (e.g. Charney, 1995; Nattrass and Seekings, 1998). Only recently has there been more work addressing directly perceptions of inequality (Klandermans et al., 2001; Seekings, 2002; ILO, 2004; Roberts, 2004a, 2004b).

These studies have generated a number of reasonably clear findings about attitudes towards inequality and redistribution in South Africa. First, most South Africans agree that the country is too unequal. The SASAS data reportedly show that South Africans are critical of the extent of inequality in South Africa, with people who consider themselves very poor or poor being more critical than those who consider themselves comfortably off. African people are more critical than white and coloured people, but Indian people are the most critical of all, and the differences are very small (Roberts, 2004b: 15). The ILO data also show that many South Africans support upper and lower limits on incomes. Almost half (44 percent) agreed that "there should be an upper limit on earned incomes" whilst over half (57 percent) agreed that "there should be a minimal income, sufficient to cover basic needs, below which nobody's income should fall”. Support for an upper limit did not vary by education or income, but support for a lower limit was stronger among the nonpoor than among the poor (ILO, 2004).

Secondly, there appears to be strong support for government interventions to help the poor. The ILO survey found strong approval of government support for the poor. Respondents remained pro-support 'even if it means that taxes must be increased for everybody earning money' (ibid.). SASAS data concur that South Africans believe that the government should take more responsibility for the poor. There was strong support for government-driven employment creation across all racial groups, but only among African people was there a majority in favour of race-based affirmative action (in employment), black economic empowerment or redistribution of land (Roberts, 2004a: 17; also Roberts, 2004b). The 2001 World Values Survey (WVS) posed a 'forced choice' question, asking that respondents placed their view on a ten-point scale 
between two different statements: 'The government should take more responsibility to ensure that everyone is provided for' and 'People should take more responsibility to provide for themselves'. Overall, using weighted data, ${ }^{1}$ almost one in two South Africans (or 46 percent, to be precise) agreed that the government should take more responsibility, whereas less than half as many (21 percent) agreed that people should take more responsibility to provide for themselves.

Thirdly, these studies suggest that race is important in South Africa, but is perhaps not as important as might have been expected and is probably declining in importance with time. Charney (1995), using focus group data, challenged the view that black South Africans had very high or unrealistic expectations of how their lives would improve after apartheid (see also Nattrass and Seekings, 1998). Although it is very difficult to measure identities, opinion polls in the 1990s generally suggested that most South Africans continued to favour racial identities over class identities. In the early 2000s, however, there were some indications of change in public attitudes. The 2003 Reconciliation Barometer found that South Africans identified as the 'biggest division' in the country 'today' not partisan or racial divisions but rather 'the division between poor and middle income/wealthy South Africans'. The SASAS conducted in the same year found that almost as many people believe that there is 'strong' or 'some' tension between rich and poor people in South Africa as between different races (Roberts, 2004b: 16).

Fourthly, overall, South Africans seem more supportive of government interventions and less tolerant of inequality than citizens in most other countries surveyed by the WVS. Cross-national ISSP data suggests that South Africans are not unusual in criticising the extent of inequality (and in fact do so less than citizens of the transitional societies of post-Communist central and East Europe) (Roberts, 2004b). Over time, white South Africans have grown much less opposed to the state assuming a major role in poverty reduction. WVS data show that, in 1991, after the onset of formal negotiations but before the first democratic elections, only 9 percent of white South Africans agreed more that the government should take responsibility for ensuring that everyone is provided for. By 1996 this had risen to 20 percent, and on to 26 percent by 2001. Conversely, the proportion agreeing more that people should take more responsibility to provide for themselves fell from 65 percent to 38 percent across the same time period.

\footnotetext{
${ }^{1}$ The weights are derived from my calculations, and reflect only racial demographics.
} 


\section{Methodological Problems with Existing South African Data}

These findings are important, but they are limited to a macro level of description and provide little opportunity for understanding the nuances of opinion that are central to the work in the USA or Hochschild, Gilens and others. South African data on attitudes towards inequality are limited in at least three ways. These might be called the 'specification', 'costing' and 'unit-ofanalysis' problems.

The specification problem concerns the problem of specifying a statement or question with sufficient precision such that it taps adequately into the normative basis of 'desert' (i.e. precisely who deserves to get what). Do questions about distribution allow for distinctions between the 'deserving' and 'undeserving' poor? The World Values Survey (WVS), for example, asks respondents whether they agree or disagree with the statement 'The government is doing too little for people in poverty'. But who, precisely, are 'people in poverty'? Respondents might believe that the government is doing too little for some poor but too much for others. In largely class-based 'northern' societies, some categories of the poor (the elderly, sick or disabled, children) are widely considered more deserving than others (the lazy). In more culturally-divided societies, desert might well be perceived to follow cultural lines (for example, a Hausa person from northern Nigeria might believe that the Nigerian government does too little to help poor Hausa people but too much to help poor Yoruba people).

The costing problem refers to the trade-offs or costs associated with redistributive policies. The World Values Survey includes sections where respondents choose between paired statements (i.e. a forced choice), but these rarely get to the heart of the trade-offs around redistribution. Thus respondents are asked to choose between 'Incomes should be made more equal' and 'We need larger income differences as incentives for individual effort', but not between pro-poor government spending and lower taxes (yet alone lower taxes for specified groups of taxpayers). Few people disagree that the poor should get more if they think that this is costless, but even the poor might baulk if the costs (perhaps to 'deserving' others as well as to the poor themselves) seem too high. Only the ILO asked about support for pro-poor policies if these meant that taxes were increased.

The unit-of-analysis problem concerns the unit of analysis, in the sense of what it is that respondents are being asked about. Questions about the 'poor' or 'black people' are asking about a group, not about individual members of these groups. Respondents might be critical of the claims made by a group but not of 
the desert of individuals within it. This problem is linked to the first, in that a group might include individuals considered deserving along with those who are not.

None of these problems is insuperable. The specification and 'individual' problems can be addressed through the use of experimental vignettes - as have been used in, for example, the study of the nuances of American attitudes around race by Sniderman and Piazza (1993). Sniderman and Piazza used a 'laid-off worker' experiment. Respondents are presented with a scenario in which a person is said to have been retrenched. The respondents are then invited to suggest how much (if any) financial assistance that person should receive from the government whilst looking for work. The scenario varies insofar as the retrenched person is given different characteristics: white or black, male or female, younger or older, single or married, with or without children, and dependable or not dependable. Sniderman and Piazza found that white, conservative Americans are less supportive of government assistance in general than white, liberal Americans, but they are - counter-intuitively - more favourably inclined to supporting black claimants (i.e. retrenched workers, in the vignette) than white claimants. Even faced with an unmarried woman with children - i.e. a claimant who violates conservative family norms - white conservative respondents are more likely to support assistance if the claimant is black than if she is white. If the claimant is described as a dependable worker in the vignette, then conservatives are especially inclined to discriminate in favour of a black person! Sniderman and Piazza continue to show that these counterintuitive findings co-exist with less surprising findings when white Americans are asked about the justice of claims made by black people as a group. The point is not that one set of responses is right and the other set wrong, but rather that people hold complex sets of beliefs. Failing to recognise this complexity, Sniderman and Piazza (1993: 86-7) conclude, leads too many commentators to see racism 'where it is not' and fail to see it 'where it is', and thus 'to ignore what they should criticise, and to criticise what they should defend.'

The costing problem can also be addressed easily, by probing the resilience of opinions in the face of explicit probing about trade-offs or costs. In a 2000 survey in poor and middle-income areas in Cape Town, we posed the following pair of questions to assess the resilience of views on pro-poor spending:

Do you agree or disagree with the following statements?

M7: The value of the old age pension should be increased

M8: The value of the old age pension should be increased even if it means that people like you have to pay higher taxes. 
Responses are shown in Figure 1. It is clear that enthusiasm for increasing pensions drops sharply if tax increases are brought into the picture, although support does not disappear. Even in the rising tax scenario, there is more support for than opposition to increasing pensions. A similar question was posed in the ILO's People's Security Survey: 'Supporting the poor costs money. Do you think more support should be given to the poor even if it means that taxes must be increased for everybody earning money?' Although the wording is problematic (see ILO, 2004: 317) and the results are not reported clearly, it seems that the question prompts changes in response broadly comparable to the 2000 Cape Town data.

Figure 1: Pro-poor Opinions in the Face of Tax Increases, Cape Town, 2000

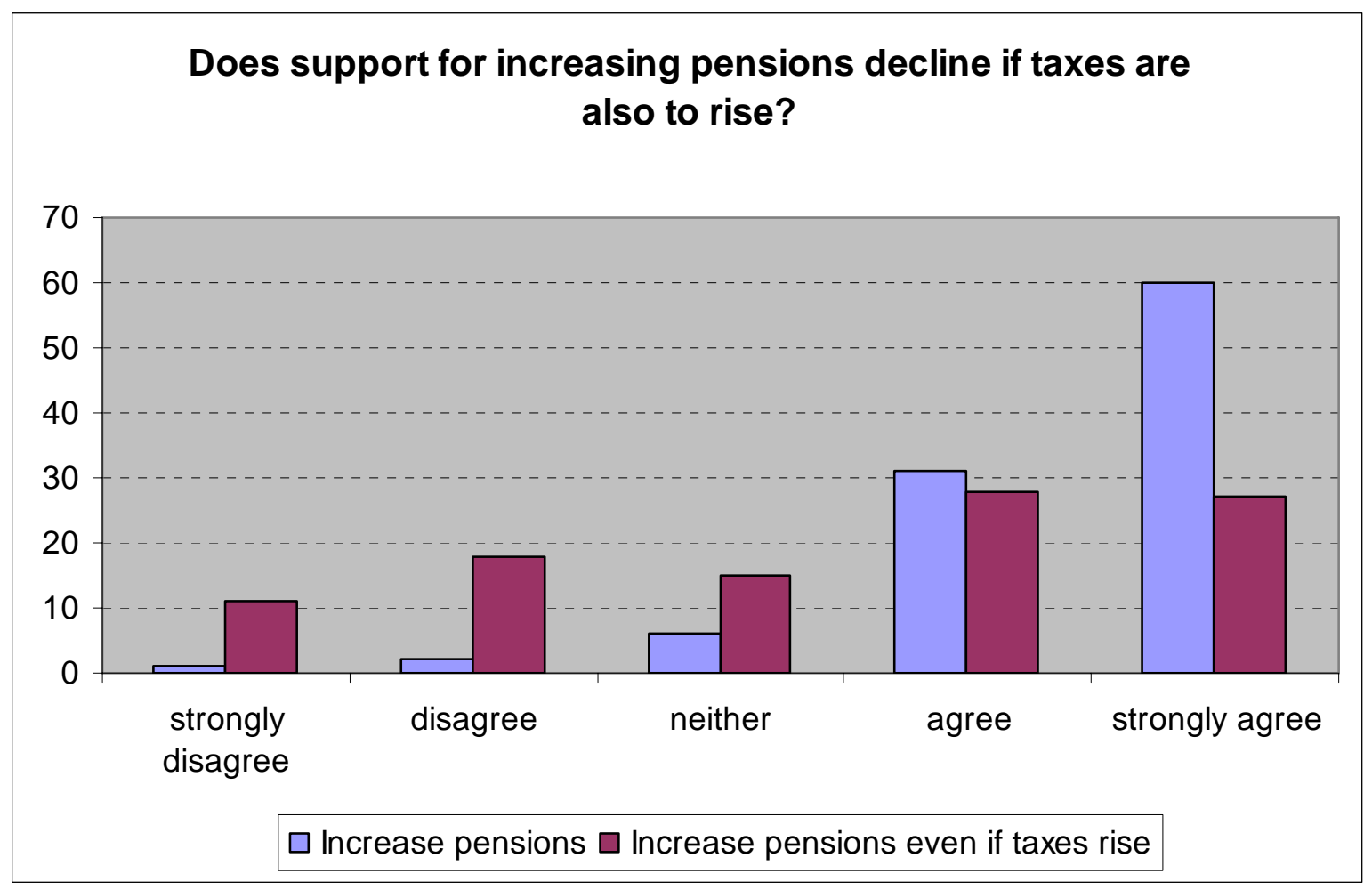

Both experimental vignettes and persuasion experiments have been used effectively in South Africa by Gibson and Gouws in their studies of tolerance (Gibson and Gouws, 2003) and reconciliation (Gibson, 2004). In this paper, I report on the use of similar techniques in a 2003 survey in Cape Town to explore nuances in attitudes towards distributive justice, and in particular to begin to address the specification, costing and unit-of-analysis problems. A separate but complementary paper probes the closely related topic of the extent to which distributive justice perceptions in South Africa are racialised. 


\section{Evidence from Cape Town}

In this paper I use data from a 2003 survey in one of South Africa's largest cities, Cape Town. Cape Town has long had a distinctive demographic, social and economic profile. Until very recently the Western Cape has never had a large 'African' population, not least because through most of the twentieth century there were tight restrictions on immigration, residence and employment for African people. Even in the early twenty-first century, half of the population of Cape Town is 'coloured', only just over one quarter is African and just under one quarter is 'white'. There is rapid immigration of African people into the city from poorer, more rural areas of the Eastern Cape, but this immigration tends to reinforce rather than erode racial segregation and inequality because immigrants tend to have few skills. There is no significant African 'middleclass' in Cape Town, in contrast to the country as a whole; nor are there any poor white people. Cape Town's population comprises a predominantly African poor, a heterogeneous coloured population, and a predominantly white upper-income group. Overall, the Gini coefficient for the distribution of income in Cape Town is about 0.58, i.e. rather less than for South Africa as a whole. The city is thus distinctively multi-racial as well as highly unequal.

The 2003 Cape Area Study (CAS), conducted by the Centre for Social Science Research at the University of Cape Town, focused on social and political attitudes and behaviour (see further Seekings, Alexander et al., 2004). It was designed not only to generate data for research but also to experiment with questionnaire design and to develop research capacity among social science students. Fieldwork was conducted in predominantly white areas by undergraduate students from the University of Cape Town and in predominantly African and coloured areas by a commercial social research company, with funding from the Mellon Foundation (as part of its support for the Centre for Social Science Research). African fieldworkers conducted the interviews in African areas and coloured fieldworkers did so in coloured areas, but in 'white' areas both the fieldworkers (university students) and the respondents were racially diverse. Fieldwork was conducted in September and October 2003.

The sample comprised 588 adults spread across metropolitan Cape Town. It in fact comprised three separate samples, one each for areas with predominantly African, predominantly coloured (or Indian) and predominantly white populations. Each of these samples was drawn using a two-stage cluster sample. Seventy 'enumerator areas' (EAs, as defined by Statistics South Africa for the 1996 Population Census) were selected on a probabilistic basis. White areas were over-sampled to cope with anticipated lower response. Then, in each EA, aerial photographs were used to select ten households. Within each household, fieldworkers were instructed to list the names and birthdays of all 
household members over the age of eighteen, and to interview whoever had the next birthday. The final, actual sample had three weaknesses. First, student fieldworkers were unable to complete their assigned interview loads, conducting a total of 188 out of the planned 200 interviews in white areas. Secondly, almost one-third of the interviews were in 'substitute' households because the fieldworkers were unable to access the sampled household or the household member with the next birthday. Thirdly, although fieldworkers appear to have complied with the 'next birthday' rule, they did end up with a sample with an implausibly high proportion of women. The data reported in this paper are weighted to adjust for race and gender, so that the weighted sample corresponds to the total population of Cape Town (according to the 2001 Population Census).

One weakness in the 2003 CAS is the poor quality of data on household incomes. Asked about household income directly, 11 percent refused or said they did not know, and 22 percent reported household income of zero. We therefore incorporated into the data-set a neighbourhood-level variable indicating the mean household income in the area. This variable was derived from data in the 2001 Population Census, using local government wards as the neighbourhood. Cape Town comprises one hundred local government wards, so that wards have an average population of between 25,000 and 30,000 people.

\section{The 'Poor' are Generally Seen as Deserving ...}

The CAS 2003 data from Cape Town confirm the finding from previous surveys that there is wide support for policies that redistribute to the poor. We asked six questions probing the perceived responsibilities of government to help the poor. The weighted distribution of responses is set out in Table 1. Question F.4 ask about equality of opportunity for children. At present, in South Africa, public spending on education is unusually progressive, and enrolment rates are very high among poor children even into secondary school, but there are big differences between the quality of schooling received. Children certainly do not leave school facing equal opportunities. Question F.38 asks about what the government is currently doing for the poor (in general), and F.12 asks whether the government should reduce inequality. The post-apartheid state claims that it does do a lot for the poor (see, for example, South Africa, 2004); elsewhere we argue that some government policies are poverty- (and inequality-) reducing but others exacerbate or even cause poverty and inequality (Seekings and Nattrass, 2004). Whatever the case, poverty and extreme inequality persist (see Seekings, Nattrass and Leibbrandt, 2004; Leibbrandt et al., 2005). Question F.6 asks about equality of outcome, but with respect to a group (the elderly) widely considered 'deserving'. In South Africa, unusually in the developing world, the 
elderly receive a quasi-universal and quite generous non-contributory old-age pension. At the time of the survey, the maximum pension was R700 (or, at the exchange rate then, about US\$100) per month present. Question F.13 asks about a 'basic income grant'. Such a grant was proposed by a government committee of inquiry in 2002, churches and trade unions; it would be payable to all citizens, but set at a low level of about R100 (US\$15) (see Seekings, 2002 and the articles in Standing and Samson, 2003). Question F.14 asks about the unemployed. Unemployment in South Africa is very high, at between 30 percent and 40 percent (depending on how unemployment is defined).

\section{Table 1: Opinions on government responsibility to help the poor}

\begin{tabular}{|l|l|c|c|c|c|c|c|c|}
\hline \multicolumn{2}{|l|}{$\begin{array}{l}\text { Here are some statements about who gets what in society, and why. For each of these statements, do you strongly } \\
\text { agree, agree, neither agree nor disagree, disagree or disagree strongly? }\end{array}$} \\
\hline \multicolumn{2}{|l|}{$\begin{array}{l}\text { Strongly } \\
\text { agree }\end{array}$} & Agree & Neither & Disagree & $\begin{array}{l}\text { Strongly } \\
\text { disagree }\end{array}$ & $\begin{array}{c}\text { Don't } \\
\text { know }\end{array}$ & Total \\
\hline F.4 & $\begin{array}{l}\text { The government should } \\
\text { ensure that children from } \\
\text { poor families have the same } \\
\text { opportunities as children } \\
\text { from richer families (\%) }\end{array}$ & 44 & 40 & 8 & 5 & 1 & 1 & 100 \\
\hline F.12 & $\begin{array}{l}\text { The government should } \\
\text { reduce the differences in } \\
\text { income between rich and } \\
\text { poor (\%) }\end{array}$ & 21 & 35 & 14 & 18 & 6 & 6 & 100 \\
\hline F.6 & $\begin{array}{l}\text { The value of the state old } \\
\text { age pension should be } \\
\text { increased (\%) }\end{array}$ & 39 & 45 & 6 & 6 & 3 & 6 & 100 \\
\hline F.13 & $\begin{array}{l}\text { The government should } \\
\text { provide everyone with a } \\
\text { guaranteed basic income } \\
\text { (like it does for old people } \\
\text { through the old-age grant) } \\
\text { (\%) }\end{array}$ & 19 & 37 & 14 & 20 & 3 & 3 & 100 \\
\hline
\end{tabular}

Support for pro-poor government policies seems to vary from strong to very strong. Massive majorities (over 80 percent) supported the government ensuring that children from poor families have the same opportunities as children from richer families (F.4), an increase in the value of the state old age pension (F.6) and government help for the unemployed (F.14). A similarly massive majority says that the government is doing 'too little' for the poor (F.38). Smaller majorities (less than 60 percent) supported the government 
reducing the differences between rich and poor (F.12) and the introduction of a basic income grant for all (F.13). Whereas there was almost no dissent from the first four statements, dissent from these last two interventions stood at about 25 percent. Overall, the picture appears to be wide but not unconditional support for pro-poor interventions.

The correlation between these items is surprisingly low (with Cronbach's alpha for the five items at 0.538, and lower still if F38 is included, using unweighted data). Factor analysis suggests that there is one significant underlying factor (with an eigenvalue of 1.6) but this explains only 40 percent of the five variables' combined variance.

The relationship between class (or race) and attitudes on these pro-poor policies shows that class (or race) affects attitudes on the different items in different ways. Figure 2 shows the percentage of respondents agreeing with each of three propositions: that the value of the old-age pension should be increased, that the government should reduce the differences in income between rich and poor, and that the government should provide everyone with a guaranteed basic income. Class is defined here simply in terms of the mean household income in the neighbourhood (measured at ward-level). There are no major differences by class (i.e. neighbourhood income quintile) with respect to the old-age pension, but there are differences with respect to a guaranteed basic income and the general proposition (that the government should reduce income differences). A low percentage in agreement might mean that respondents disagreed, disagreed strongly or said that they neither disagreed or disagreed strongly. The strongest disagreement with the general proposition was in middle-income areas (with many respondents in the richest opting for the 'neither' response).

Regressing the composite variable derived from the factor analysis against race alone suggests that there is a significant but weak race effect, with being white correlating with a less pro-poor attitude; the coefficient of determination (i.e. $r^{2}$ ), however, is very low (0.04). Gender, age, marital status and parental status are not significant, add little to the explanatory power of the model and do not affect the significance of race, but adding in education removes the effect of being white relative to being African and adding in an affluence variable largely removes the effect of being white relative to being coloured. Even with all of these variables included in the model, the $\mathrm{r}^{2}$ remains low at 0.08 . The effects of race appear to be generally weak and differentiated. This is considered in more detail in a separate paper (Seekings, 2005). 
Figure 2: Support for pro-poor policies, by income in neighbourhood

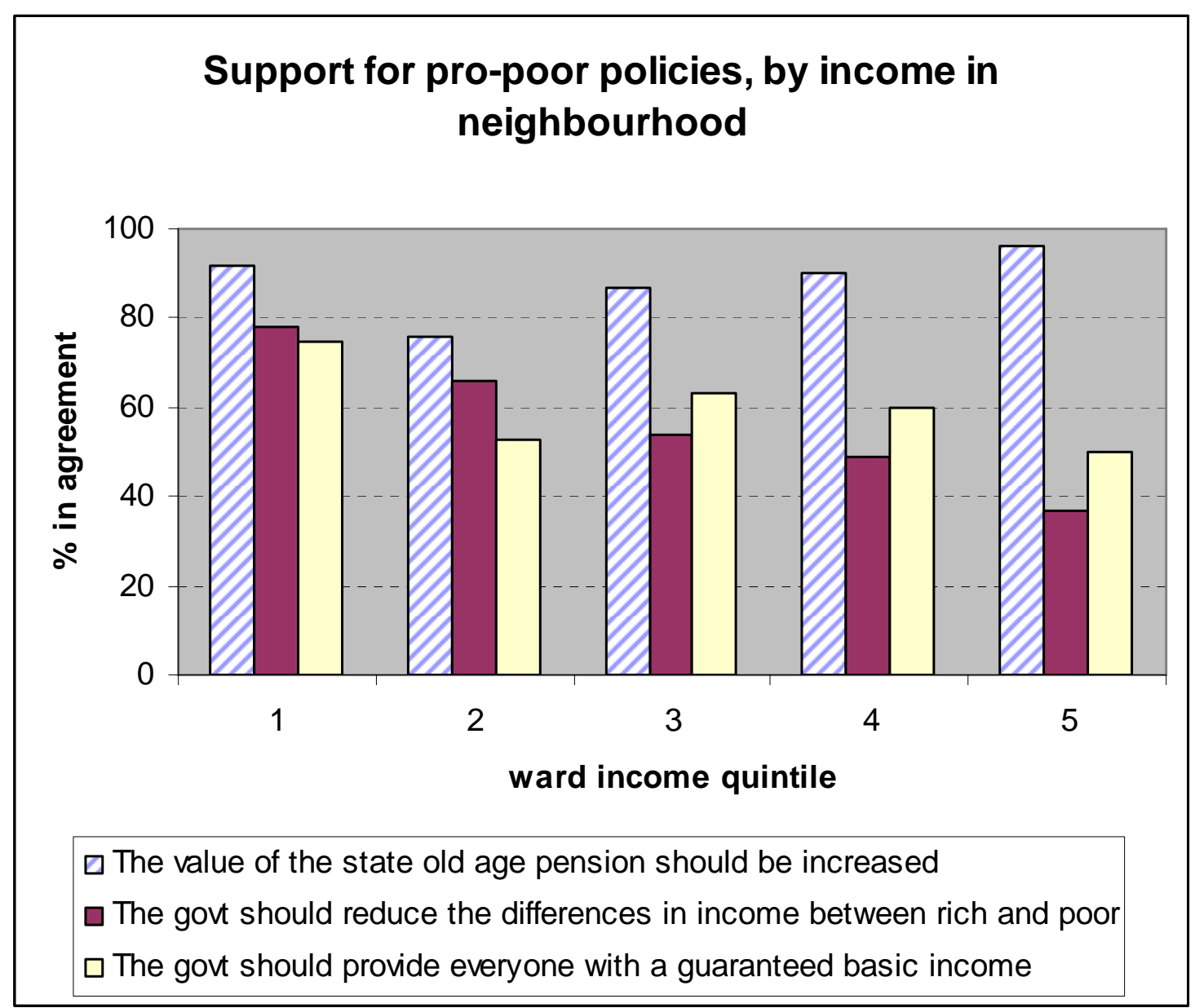

\section{... But Some Poor People are Considered More Deserving than Others}

Capetonians appear to be broadly supportive of pro-poor policies. But already there are signs that some respondents are discerning between different pro-poor interventions, and hence perhaps different categories of poor people. The overwhelming support for increased old-age pensions (F.6) and for equal opportunities for children (F.4), even among the less pro-poor white respondents, suggest that the elderly and children are seen as highly deserving. In contrast, more respondents - including a majority of white respondents - are opposed to a universal basic income grant (F.13). The unemployed are seen as a deserving category, unsurprisingly in a society in which so much unemployment is involuntary. 
The experimental vignettes included in CAS 2003 provide a more nuanced set of insights into the ways in which desert is linked to the characteristics of the beneficiary as well as those of the respondent. One vignette was a version of Sniderman and Piazza's retrenched worker experiment. Respondents were told: 'The government provides grants to some people in need, especially the elderly. I am going to describe a situation, and then ask you what the government should do to help the person involved.' The description takes the following form:
A worker has been retrenched from a company. [He/she] is a [white/coloured/African] [man/woman], in [his/her] [20s/30s/40s], [single/married] and [with/without] children. [He/she] is a [dependable/not dependable] worker and now [is/is not] actively looking for work.

Ten different scenarios were used, each of which was presented to about sixty respondents. The first scenario, for example, was: 'A worker has been retrenched from a company. He is a white man, in his 40s, married and with children. He is a dependable worker and is actively looking for work.' The respondent is then asked: 'Should the Government provide financial assistance to this person whilst he/she is unemployed?' If the respondent says 'yes', he or she is then asked 'how much?'. We tried to ensure that each scenario was used in each EA in our sample so that the sub-samples for each scenario were broadly similar (i.e. in terms of the characteristics of the respondents).

In South Africa there is no general public financial assistance for the unemployed. The Unemployment Insurance Fund provides earnings-related assistance for a limited period of unemployment, but only to people who have contributed to the fund in the past. Its limited duration and exclusion of noncontributors mean that only a very small proportion of the unemployed receive UIF benefits. Most unemployed are compelled to rely on their own savings or, more generally, their kin. The general scenario would therefore probably be understood as an extension of the existing welfare system.

Table 2 shows the percentage of respondents approving of financial assistance, and the mean amounts suggested (with amounts of zero entered if the respondent was opposed to government support), for each of the ten specified sets of characteristics of the retrenched worker. Overall, six out of ten respondents favoured financial assistance to the retrenched worker, with three out of ten respondents saying 'no', 7 percent saying 'maybe' or 'it depends' and just 2 percent saying that they did not know. The variations between the scenarios were relatively small. A maximum of 76 percent of respondents supported financial assistance for a married, white man, in his 40s and with children, who was a dependable worker and was actively looking for work 
(scenario \#1). A minimum of 49 percent approved financial assistance to an unmarried, childless, white man in his 20s (scenario \#3). An almost identical proportion (50 percent) approved financial assistance to his African equivalent (despite the added stipulation that he was a dependable worker and was actively looking for work - scenario \#5). These three cases indicate that the classic male breadwinner is deemed more deserving than the unmarried, childless young man, perhaps indicating a conservative, family-oriented conception of desert.

\section{Table 2: Assessments of desert, according to the scenario used}

\begin{tabular}{|c|c|c|c|c|c|c|c|c|c|c|c|}
\hline \multirow{2}{*}{$\begin{array}{l}\text { Scen- } \\
\text { ario }\end{array}$} & \multicolumn{6}{|c|}{ Characteristics of the retrenched worker } & \multicolumn{5}{|c|}{ Respondents' assessment of desert } \\
\hline & Gender & $\begin{array}{c}\text { Popula- } \\
\text { tion } \\
\text { group }\end{array}$ & age & Married? & $\begin{array}{l}\text { Has } \\
\text { child } \\
\text {-ren? }\end{array}$ & $D^{*}$ & $\begin{array}{c}\% \\
\text { say } \\
\text { yes }\end{array}$ & $n$ & $\begin{array}{c}\text { Mean } \\
\text { amount } \\
\text { (R) if } \\
\text { yes }\end{array}$ & $n$ & $\begin{array}{c}\text { Mean } \\
\text { amount } \\
(R) \text { if } \\
\text { yes or } \\
\text { no }\end{array}$ \\
\hline 1 & Male & white & $40 \mathrm{~s}$ & Yes & yes & yes & 76 & 65 & 1302 & 47 & 993 \\
\hline 2 & Female & White & $30 s$ & No & Yes & - & 59 & 53 & 907 & 32 & 514 \\
\hline 3 & Male & White & $20 \mathrm{~s}$ & no & No & - & 49 & 61 & 769 & 30 & 356 \\
\hline 4 & Male & African & $40 \mathrm{~s}$ & yes & Yes & - & 61 & 61 & 834 & 38 & 533 \\
\hline 5 & Male & African & $20 \mathrm{~s}$ & no & no & yes & 50 & 57 & 899 & 30 & 438 \\
\hline 6 & Female & African & $20 s$ & no & Yes & - & 67 & 61 & 1039 & 40 & 711 \\
\hline 7 & Female & African & $30 \mathrm{~s}$ & yes & No & yes & 63 & 50 & 991 & 32 & 689 \\
\hline 8 & Male & coloured & $30 \mathrm{~s}$ & no & no & yes & 58 & 59 & 689 & 36 & 398 \\
\hline 9 & Female & Coloured & $40 \mathrm{~s}$ & yes & Yes & - & 62 & 63 & 1036 & 39 & 642 \\
\hline 10 & Female & coloured & $20 \mathrm{~s}$ & no & No & yes & 60 & 58 & 753 & 33 & 482 \\
\hline Total & & & & & & & 60 & 588 & 935 & 357 & 573 \\
\hline
\end{tabular}

Notes: data are weighted. D* is “dependable and looking for work”.

The pattern in the amounts that respondents awarded is broadly similar to the pattern of whether they favoured financial assistance at all. The amounts awarded were notional in that the question asked how much should the government provide per month. In Table 2, the first column for 'mean amount' of award includes only those awards greater than zero. There is considerable variation, with the mean award in the most deserving scenario - the older, married white man with children, who is a dependable worker and is actively looking for work (scenario \#1) is almost double the mean award in the least deserving scenario - the coloured man, in his 30s, single and without children, but a dependable worker and actively looking for work (scenario \#8). Measured in terms of the amount awarded, the three most deserving scenarios (\#1, 6 and 9) all entailed retrenched workers with children, and the three least deserving scenarios (\#3, 8 and 10) all entailed retrenched workers without children. 
The final column for 'mean amount if yes or no' in Table 2 sets a value of 0 for cases where the respondent did not consider that the beneficiary should receive government assistance. The figures in this column thus combine the effects of both decisions, i.e. whether the beneficiary is deemed deserving and how much he/she should receive. These data confirm that scenarios \#1 and 6 involve the most deserving cases, and scenarios \#3 and 8 the least deserving cases. Overall, the mean award in the most deserving case (\#1, male white breadwinner) is almost three times larger than the mean award in the least deserving case (\#3, young white man). Again, the most deserving scenarios both entailed having children, and the two least deserving scenarios entailed not having children.

The analytic power of vignettes lies primarily in analysing the effects of specific characteristics in a pooled sample not in comparing the results of scenarios presented to different sub-samples. Elsewhere (Seekings, 2005), I explore the correlates of differential assessments, focusing especially on the significance of race relative to other factors (using race variables for both the supposed beneficiary in the vignette and for the respondent). The basic findings are simple: race is not significant in the initial assessment of desert, but in assessing the amount of an award, race becomes significant, although in initially counterintuitive ways. White respondents are more generous, perhaps because they cannot imagine living on low incomes. And, controlling for other variables, white subjects receive larger awards from all respondents. The only interpretation I can provide for this is that respondents are using an incomereplacement approach to assessing awards: larger awards are given to people who have previously enjoyed higher incomes.

\section{Introducing Strong Grounds for Discrimination}

Respondents in our survey discriminated in terms of whether to make an award to the supposed subject and, if they thought an award should be made, in how large an award. In combination, as we have seen, these resulted in large variations in the mean award made. But most of this variation arose from second stage of assessment, i.e. how large an award. Discrimination in the initial assessment of desert was relatively limited, ranging from a low of 49 percent support for an award in the least deserving case to a high of 76 percent in the most deserving case. It would seem that the manipulation of the characteristics of the subject or beneficiary within a limited range made little difference to their perceived desert, regardless of the characteristics of the respondent. CAS 2003 included another step allowing us to probe further the nature of perceived desert in South Africa. A persuasion exercise was introduced immediately following the retrenched worker vignette. The persuasion exercise provided additional and, on the face of it, probably 
compelling information about the beneficiary to the respondent. Would the addition of much more compelling information about the beneficiary have a larger effect on perceived desert than the limited manipulation of characteristics in the vignette itself?

If the respondent had initially favoured financial assistance to the retrenched worker, he or she was then asked (G.7) 'Suppose that a friend told you that people like this person spend their money on alcohol. Should the Government still provide financial assistance to this person?' If the respondent had initially opposed financial assistance, he or she was then asked (G.8) 'Suppose that this person was going to get sick or even die because he/she could not afford food. Should the government then provide financial assistance to this person?' and then (G.9) 'Suppose that this person's children were going to go hungry and drop out of school. Should the government then provide financial assistance to this person?'. For each question, response options were 'yes', 'no', 'maybe' or 'it depends', and 'don't know'.

The effects of this additional information were huge (see Table 3 and Figure 3). Respondents could quite easily be persuaded to change their views when provided with additional information. Of the respondents who initially agreed that the government should assist the unemployed person in the vignette, 71 percent changed their minds when told that the beneficiary might spend the money on alcohol. As a proportion of the total sample, support for government assistance fell from 60 percent to just 11 percent (i.e. 0.17 x 0.6). Similarly, of the respondents who initially said that the government should not assist the unemployed person, 57 percent changed their mind faced with the prospect of the unemployed person falling sick and perhaps dying, and 61 percent changed their mind when told that the person's children were going to go hungry and drop out of school. As a proportion of the total sample, opposition to support dropped from 31 percent initially to just 8 percent when faced with counterarguments about the possible consequences of poverty for the individual. The partial exception to the persuasive power of additional information is the case of tax increases. Only one in five respondents who had initially supported financial assistance changed their mind when told that taxes might increase.

The large effects of this additional information (excepting on tax) stand in contrast with the relatively muted effects of the characteristics of the beneficiary introduced in the vignettes themselves. There are two possible reasons for this. First, the additional information posed much more extreme scenarios in terms of desert. Respondents seem more swayed by issues of individual need and behaviour than they are by general socio-demographic factors. Secondly, the results might be influenced by the methodology: the persuasion format and phrasing might encourage respondents to change their minds. This suggests 
some lessons for the design of experiments of this sort. Ideally, some respondents would have been provided with this additional information in the original vignettes, whilst others would be presented with some of the original information (such as race) in the persuasion format. This would allow for a separation of the effects of the characteristics of the subject from methodological effects.

Table 3: Responses to Persuasion (weighted data)

\begin{tabular}{|c|c|c|c|}
\hline \multicolumn{2}{|c|}{ Question } & Response & $\%$ \\
\hline \multirow[t]{4}{*}{ G.3 } & \multirow{4}{*}{$\begin{array}{l}\text { Should the government provide financial assistance } \\
\text { to this person [with varied characteristics] whilst } \\
\text { he/she is unemployed? }\end{array}$} & Yes & 60 \\
\hline & & No & 31 \\
\hline & & $\begin{array}{l}\text { Maybe/it depends/don’t } \\
\text { know }\end{array}$ & 9 \\
\hline & & Total & 100 \\
\hline \multirow{4}{*}{$\begin{array}{l}\text { G. } 6 \\
\text { Only if } \\
\text { yes to } \\
\text { G.3 }\end{array}$} & \multirow{4}{*}{$\begin{array}{l}\text { G.6: Suppose that the Government said that it had to } \\
\text { increase taxes to pay for these grants to the } \\
\text { unemployed. Do you still believe that the } \\
\text { Government should provide financial assistance to } \\
\text { this person? }\end{array}$} & Yes & 67 \\
\hline & & No & 20 \\
\hline & & $\begin{array}{l}\text { Maybe/it depends/don’t } \\
\text { know }\end{array}$ & 13 \\
\hline & & Total & 100 \\
\hline \multirow{4}{*}{$\begin{array}{l}\text { G. } 7 \\
\text { Only if } \\
\text { yes to } \\
\text { G.3 }\end{array}$} & \multirow{4}{*}{$\begin{array}{l}\text { G.7: Suppose that a friend told you that people like } \\
\text { this person spend their money on alcohol. Should } \\
\text { the Government still provide financial assistance to } \\
\text { this person? }\end{array}$} & Yes & 17 \\
\hline & & No & 71 \\
\hline & & $\begin{array}{l}\text { Maybe/it depends/don't } \\
\text { know }\end{array}$ & 11 \\
\hline & & Total & 100 \\
\hline \multirow{4}{*}{$\begin{array}{l}\text { G.8 } \\
\text { Only if } \\
\text { no to } \\
\text { G.3 }\end{array}$} & \multirow{4}{*}{$\begin{array}{l}\text { G.8: Suppose that this person was going to get sick } \\
\text { or even die because he/she could not afford food. } \\
\text { Should the government then provide financial } \\
\text { assistance to this person? }\end{array}$} & Yes & 57 \\
\hline & & No & 25 \\
\hline & & $\begin{array}{l}\text { Maybe/it depends/don’t } \\
\text { know }\end{array}$ & 18 \\
\hline & & Total & 100 \\
\hline \multirow{4}{*}{$\begin{array}{l}\text { G.9 } \\
\text { Only if } \\
\text { no to } \\
\text { G.3 }\end{array}$} & \multirow{4}{*}{$\begin{array}{l}\text { G.9: Suppose that this person's children were going } \\
\text { to go hungry and drop out of school. Should the } \\
\text { government then provide financial assistance to this } \\
\text { person? }\end{array}$} & Yes & 61 \\
\hline & & No & 25 \\
\hline & & $\begin{array}{l}\text { Maybe/it depends/don’t } \\
\text { know }\end{array}$ & 13 \\
\hline & & Total & 100 \\
\hline
\end{tabular}




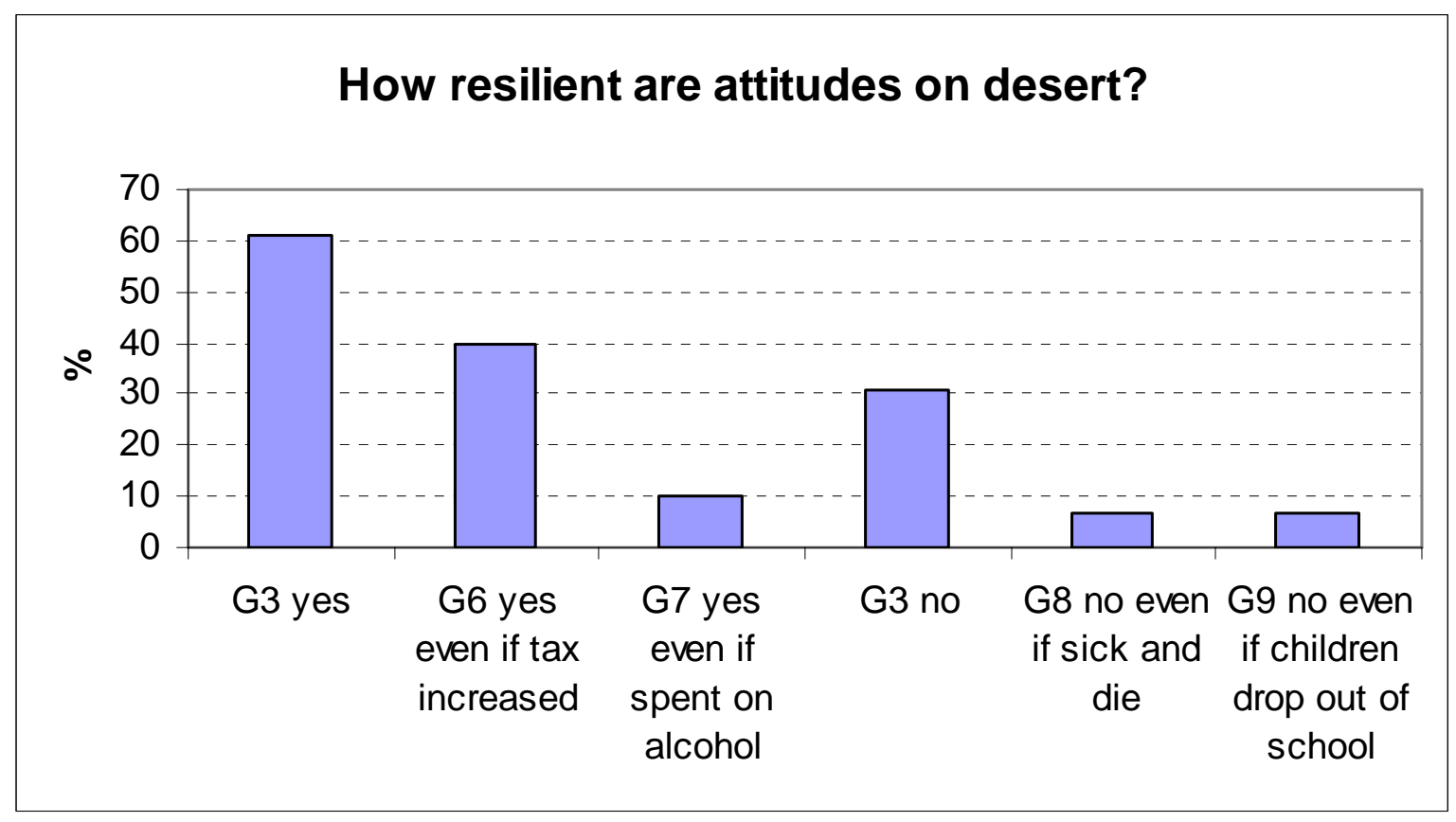

Is the mutability of attitudes related to either the characteristics of the respondent or those of the supposed beneficiary? One might imagine that, for example, some respondents might be more punitive of drinkers than others, whilst some categories of beneficiary (mothers, perhaps) might be deemed disproportionately more deserving if they are at risk of falling sick.

In comparison to the regressions run on the initial responses to the vignettes, these new regressions run on changing responses show stronger results. For G.7, regressing change of opinion against the various original characteristics of beneficiary and respondent results in a $\mathrm{r}^{2}$ of 9 percent; the only variable with a statistically significant relationship with change of opinion is the respondent being coloured (relative to being white, that is). Coloured respondents are more likely to punish a drinker by changing their mind and opposing financial assistance. For G.8 and G.9, few of the characteristics of the respondent have a statistically significant relationship with whether or not he or she changes his/her mind and now supports financial assistance; the exceptions are whether the respondent is working (which makes it less likely that he or she will change his opinion) and (for G.8 but not G.9) if he/she is African (which makes it more likely that he or she will change his/her mind). But most of the characteristics of the beneficiary are statistically significant: the respondent is more likely to change his/her mind if the beneficiary is female, African, older or unmarried, and less likely if the beneficiary is coloured. Perversely, the respondent is also less likely to change his/her mind if the beneficiary has children (but this finding might be viewed with caution, as G.9 should not have been asked in 
cases where the beneficiary was described in the original vignette as not having children). Overall, the $r^{2} s$ for these probits on G.8 and G.9 are 25 percent and 19 percent respectively.

\section{Wide but not so Shallow: Taxation and Desert}

Support for democracy in Africa is 'wide but shallow', argue Bratton et al. (2004: chapter 3) using Afrobarometer data. By this, they means that most ordinary people across Africa say that they support democracy, preferring it to alternative forms of government, but 'prodemocracy sentiments may be a veneer beneath which lasting democratic commitments, behaviours and habits have yet to take root' (ibid: 85). Is the same true in South Africa with regard to support for reducing inequality through public expenditure? Crucially, how does the prospect of paying taxes affect support for public expenditure?

\section{Table 4: Attitudes towards taxation}

\begin{tabular}{|l|l|c|c|c|c|c|c|c|}
\hline \multicolumn{2}{|c|}{ Here are some statements about who gets what in society, and why. For each of these statements, do } \\
you strongly agree, agree, neither agree nor disagree, disagree or disagree strongly? \\
\hline \multicolumn{2}{|l|}{$\begin{array}{l}\text { Strongly } \\
\text { agree }\end{array}$} & Agree & Neither & $\begin{array}{c}\text { Dis- } \\
\text { agree }\end{array}$ & $\begin{array}{c}\text { Strongly } \\
\text { disagree }\end{array}$ & $\begin{array}{c}\text { Don't } \\
\text { know }\end{array}$ & Total \\
\hline F.11 & $\begin{array}{l}\text { Taxation should be } \\
\text { increased so that more } \\
\text { money is available for the } \\
\text { government to spend (\%) }\end{array}$ & 4 & 9 & 12 & 41 & 29 & 5 & 100 \\
\hline F.9 & $\begin{array}{l}\text { Poor people pay too much } \\
\text { tax (\%) }\end{array}$ & 17 & 31 & 11 & 23 & 7 & 11 & 100 \\
\hline F.10 & $\begin{array}{l}\text { People like you pay too } \\
\text { much tax (\%) }\end{array}$ & 21 & 35 & 11 & 19 & 7 & 7 & 100 \\
\hline F.7 & $\begin{array}{l}\text { The government old age } \\
\text { pension should be increased } \\
\text { even if it means that people } \\
\text { like you have to pay higher } \\
\text { taxes (\%) }\end{array}$ & 20 & 34 & 12 & 20 & 10 & 4 & 100 \\
\hline
\end{tabular}

In Cape Town, we found that strong support for pro-poor policies co-exists with strong opposition to tax increases (see Table 4). A majority of respondents believe that people like them pay too much tax and a very clear majority (70 percent) is opposed to increasing taxes to finance more spending. More than half of our sample said that people like them paid too much tax. Responses to our different questions about tax varied by class, measured again in terms of the mean household income in the neighbourhood (i.e. the local government ward) (see Figure 4). In richer areas, respondents were more likely to be opposed to 
increasing taxation to fund increased state spending (F.11). But the pattern is more complex for the other questions. Respondents in the poorest neighbourhoods do not agree that poor people pay too much tax (F.9) or that people like them pay too much tax (F.10). Agreement with these two statements is strongest not in the richer areas, but in the second and third ward income quintiles.

Figure 4: Opposition to tax increases, by neighbourhood

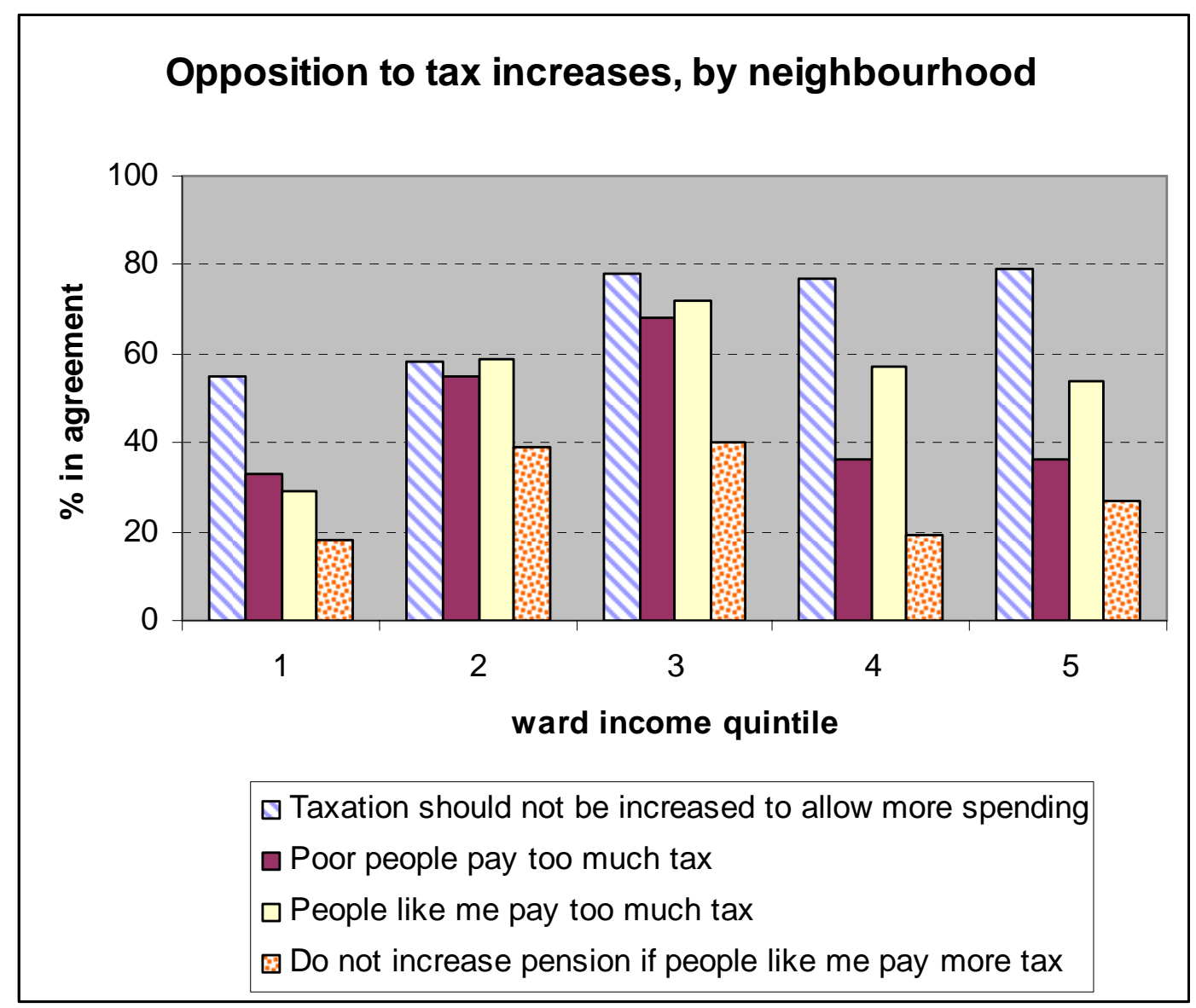

When tax increases are linked to the deserving poor, however, the discouraging effects of cost are muted. Support for increasing the old-age pension does drop when the implication of tax increases 'for people like you' is specified, but only from 84 percent (when there is no mention of tax increases) to 54 percent. Opposition more than triples, from 9 percent to 30 percent (see Table 4 and Figure 4). Opposition is strongest not among the rich, but among respondents in the second and third ward income quintiles. Overall, almost 50 percent of respondents became less supportive (for example, shifting from 'strongly agree' to merely 'agree' or from 'neither agree nor disagree' to 'disagree'). Nonetheless, even with the tax increase specification, a majority of respondents 
still supported increasing the value of the old-age pension. ${ }^{2}$ Similarly, in the 'retrenched worker' experiment, only 21 percent of the respondents who supported financial assistance changed their minds when faced with a likely tax increase to pay for it. This compares to 70 percent who changed their minds when faced with the information that the beneficiary might spend the grant on alcohol. In short, taking tax into account influences some people's assessment of desert, but not nearly as much as taking into account aspects of the behaviour of the poor themselves.

We can compare the respondents who became less supportive of increasing oldage pensions when the issue of tax increases was raised with those respondents who were as supportive with the tax caveat. Being white or being rich made a respondent much less likely to become less supportive of increasing the pension. $^{3}$ It is perhaps unsurprising that richer people feel that they can accommodate an increase in tax more easily than a poor person, but it is curious that the coefficient for being white is negative even when in a multivariate regression that takes being rich into account separately. This is perhaps evidence for the argument I have advanced elsewhere (Seekings, 2004) that the coincidence of racial privilege with class privilege makes white South Africans unusually willing (for a developing country society) to support redistribution to the deserving poor.

CAS 2003 also included a question about taxation in the persuasion component of the 'retrenched worker' vignettes. Respondents who initially favoured public assistance to the subject described in the vignette were then asked (G.6) 'Suppose that the Government said it had to increase taxes to pay for these grants to the unemployed. Do you still believe that the Government should provide financial assistance to this person?' Initially, 60 percent of all respondents (faced with the various scenarios) said that the subject should receive financial assistance from the government. Of these, two-thirds said that the subject should receive support even if it meant that taxes were increased. In other words, 40 percent of respondents said that the subject should receive

\footnotetext{
${ }^{2}$ The distribution of responses to these two questions in 2003 was very similar to the distribution in the 2000 KMPS (Seekings, 2002: 13-14; note that the scoring in KMPS was the reverse of CAS2003). KMPS did find less opposition to tax increases for unspecified purposes, presumably reflecting the absence of upper income respondents in that survey.

${ }^{3}$ The dprobit coefficients are 0.17 for being African and 0.22 for being coloured (both relative to being white), and -0.22 for being rich. A similar multivariate dprobit regression for changing opinion in G.6 finds insignificant race effects but a similarly significant and negative income effect (with the dprobit coefficient being -0.17). Both regressions used the full set of respondent socio-demographic characteristics used in Appendix A. All four of these relationships are significant at the 1 percent level. A survey in African and coloured areas of Cape Town in 2000 found similar evidence of aversion to tax-funded pension increases among poor African and coloured respondents (see Seekings, 2002).
} 
support even if taxes had to be raised. This again underscores the resilience of support for redistribution in the face of the costs thereof, especially when compared to the lack of resilience of support for redistribution in the face of bad behaviour by the poor themselves.

\section{Conclusion}

We have seen that most but not all respondents see a wide range of poor people as deserving of public assistance, but that they discriminate on the basis of the characteristics of the beneficiary. Many respondents seem to assess old people and children as being more deserving than people in general, favouring increased old-age pensions and assistance for children more than they favour a basic income grant for all. In the vignette, however, the specified characteristics of the retrenched worker made relatively little difference to the initial assessment of desert. Only when we introduced additional information - about the beneficiary drinking, falling sick or being unable to keep a child in school did the characteristics of the beneficiary make a big difference to perceived desert. Accepting that this final result probably reflects in part the methodology, it does seem likely that respondents are influenced less by the race and other social and demographic characteristics of the beneficiary than they are by the beneficiary's behaviour (drinking) or need (in terms of the real consequences of post-retrenchment poverty). This finding must be viewed as inconclusive, but it is striking.

The prospect of higher taxation does diminish support for pro-poor policies, but not by as much as negative information about the behaviour of the poor themselves. Tax increases seem less important than welfare recipients spending their grants on alcohol. Being white or rich actually made respondents less likely to change their opinions when faced with the prospect of tax increases.

Figure 5 summarises the range of responses in assessments of desert. Almost everyone supports proposals such as increasing the value of the old-age pension, helping the unemployed and ensuring equal opportunities for poor and rich children. Very small majorities support a guaranteed basic income for all, or increasing the pension if it means increasing taxes also. The different versions of the retrenched worker vignette elicited positive responses from between 49 and 76 percent of respondents. But, when told that people like the retrenched worker spent their money on alcohol, only 10 percent of respondents supported financial assistance. This was more or less the same proportion as that which favoured tax increases to finance generally higher government spending. 


\section{Figure 5}

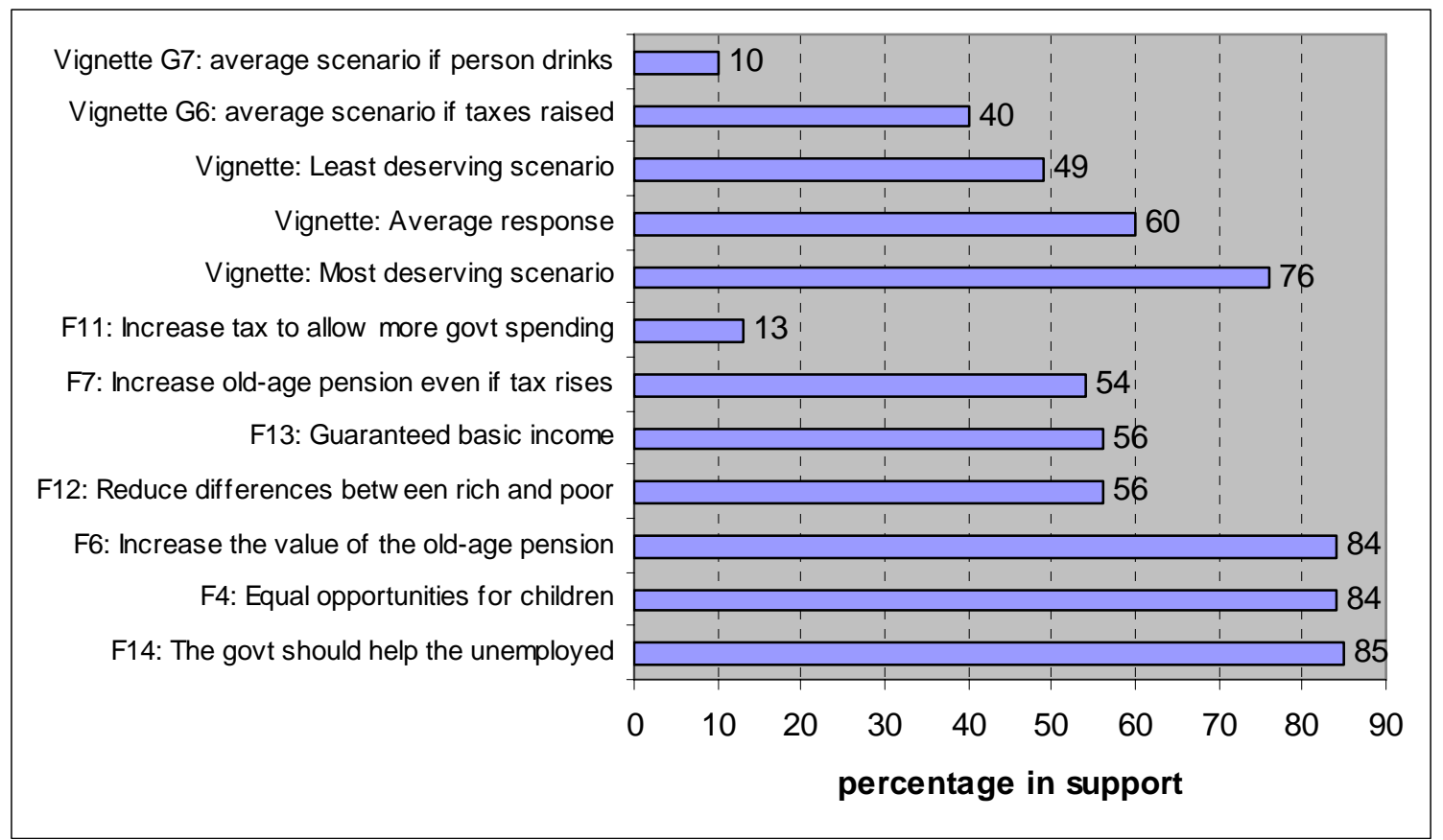

Respondents are open to persuasion. Figure 3 showed that assessments of desert are not very resilient in the face of counter-arguments. Most respondents who initially assessed that the subject in the vignette should receive financial assistance changed their minds when faced with counter-arguments about tax or the spending patterns of welfare-recipients. Similarly, few respondents who initially did not think that the subject was deserving stuck by this view in the face of strong counter-arguments about the possibility of negative effects on the subject's health or children's schooling.

Assessments of desert in South Africa, as in other places, are heavily dependent on the specification of the situation. Some poor people are seen to be deserving, others less or or not at all. Unlike in the USA, constructions of desert in South Africa do not appear to be informed significantly by racial stereotypes. Overall, many poor people are considered deserving, probably because they are seen as victims of situations beyond their control (old age, poor parents, unemployment). This results in high overall levels of support for pro-poor policies to benefit the deserving poor. But this does not mean blanket support for redistribution. 


\section{References}

Alesina, Alberto, and Edward L. Glaeser (2004), Fighting Poverty in the US and Europe (Oxford: Oxford University Press).

Bratton, Michael, Robert Mattes and E. Gyimah-Boadi (2004), Public Opinion, Democracy and Market Reform in Africa (Cambridge: Cambridge University Press).

Charney, Craig (1995), 'Voices of a New Democracy: African Expectations in the New South Africa', Research Report no. 38 (Johannesburg: Centre for Policy Studies).

Esping-Andersen, Gosta (1990), The Three Worlds of Welfare Capitalism (Princeton: Princeton University Press).

Gibson, James L. (2004), Overcoming Apartheid: Can Truth Reconcile a Divided Nation? (Pretoria: Human Sciences Research Council Press).

----- \& Amanda Gouws (2003), Overcoming Intolerance in South Africa: Experiments in Democratic Persuasion (Cambridge: Cambridge University Press).

Gilens, Martin (1999), Why Americans Hate Welfare: Race, Media, and the Politics of Antipoverty Policy (Chicago: University of Chicago Press).

Hochschild, Jennifer L. (1981), What's Fair? American Beliefs about Distributive Justice (Cambridge MA: Harvard University Press).

International Labour Organisation (2004), Economic Security for a Better World (Geneva: International Labour Office).

Klandermans, Bert, Marlene Roefs \& Johan Olivier (eds) (2001), The State of the People: Citizens, Civil Society and Governance in South Africa, 19942000 (Pretoria: Human Sciences Research Council).

Klasen, S. (1997), 'Poverty, Inequality and Deprivation in South Africa', Social Indicators Research 41: 51-94.

Kluegel, J.R., D.S. Mason and B.Wegener (eds) (1995), Social Justice and Political Change: Public Opinion in Capitalist and Post-Communist States (New York: Aldine de Gruyter).

Leibbrandt, Murray, Laura Poswell, P. Naidoo, Matthew Welch and Ingrid Woolard (2004), 'Measuring recent changes in South African inequality and poverty using 1996 and 2001 census data', CSSR Working Paper no. 84 (Cape Town: Centre for Social Science Research, University of Cape Town).

Lombard, Karin (2003), 'Prospects for Reconciliation: Race and Class', unpublished paper. 
May, Julian, and Andy Norton (1997), '”A Difficult Life”: The Perceptions and Experience of Poverty in South Africa', Social Indicators Research vol. 41: 95-118.

Nattrass, Nicoli and Jeremy Seekings (1998), 'Growth, democracy, and expectations in South Africa', in Iraj Abedian and Michael Biggs (eds), Economic Globalisation and Fiscal Policy (Cape Town: Oxford University Press): 27-53.

Osberg, Lars and Timothy Sneeding (2004), '”Fair” Inequality? An International Comparison of Attitudes to Pay Differentials', unpublished paper.

Reis, Elisa, and Mick Moore (eds) (2005 forthcoming), Elite Perceptions of Poverty and Inequality (London: Zed Books).

Roberts, Ben (2004a), 'Confronting the Divide: Attitudes to Inequality', HSRC Review vol. 2, no.4.

----- (2004b), 'The Happy Transition? Attitudes to Poverty and Inequality after a Decade of Democracy', unpublished paper.

Sangoco (1998), The People's Voices: National Speak Out on Poverty Hearings, March-June 1998 (Johannesburg: South African National NGO Coalition).

Scalon, Celi (ed.) (2004), Imagens da Desigualdade (Belo Horizonte: Editora UFMG).

Seekings, Jeremy (2002a), 'Unemployment and Distributive Justice in South Africa: Some Inconclusive Evidence from Cape Town', CSSR Working Paper no. 24 (Cape Town: Centre for Social Science Research, University of Cape Town).

----- (2002b), 'The Broader Importance of Welfare Reform in South Africa', Social Dynamics 28,2: 1-38.

----- (2004), 'Institutional Design, Cultural Diversity and Economic Solidarity: A Comparison of South Africa, Brazil and Nigeria', in Philippe van Parijs (ed.), Cultural Diversity versus Economic Solidarity (Brussels: De Boeck).

----- (2005), 'The Colour of Desert: Race, Class and Distributive Justice in Postapartheid South Africa', CSSR Working Paper no. 126 (Cape Town: Centre for Social Science Research, University of Cape Town).

-----, Karin Alexander, Tracy Jooste and Isaac Matzner (2004), 'The 2003 Cape Area Study (CAS3): A User's Guide', CSSR Working Paper no. 61 (Cape Town: Centre for Social Science Research, University of Cape Town). 
-----, with Tracy Jooste, Mirah Langer and Brendan Maughan-Brown (2005), 'Inequality and Diversity in Cape Town: An Introduction and User's Guide to the 2005 Cape Area Study', CSSR Working Paper no. 124 (Cape Town: Centre for Social Science Research, University of Cape Town).

----- \& Nicoli Nattrass (2004), 'The Post-apartheid Distributional Regime', CSSR Working Paper no. 76 (Cape Town: Centre for Social Science Research, University of Cape Town).

----- \& ----- (2005), Class, Race and Inequality in South Africa (New Haven: Yale University Press).

-----, with ----- and Murray Leibbrandt (2004), 'Income Inequality After Apartheid', CSSR Working Paper no. 75 (Cape Town: Centre for Social Science Research, University of Cape Town).

Sniderman, Paul, and Thomas Piazza (1993), The Scar of Race (Cambridge, MA: Belknap Press).

South Africa (2004), Ten Year Review (accessed online).

Standing, Guy \& Michael Samson (eds) (2003), A Basic Income Grant for South Africa (Cape Town: University of Cape Town Press). 


\section{Appendix A: Perceived desert, by characteristics of 'beneficiary' and respondent}

\begin{tabular}{|c|c|c|c|c|c|c|}
\hline \multirow{3}{*}{\multicolumn{2}{|c|}{ Characteristic of retrenched worker }} & \multirow[t]{2}{*}{ \% say yes } & \multirow[t]{2}{*}{$N$} & \multirow[t]{2}{*}{$\begin{array}{l}\text { Mean } \\
\text { amount } \\
(R)\end{array}$} & \multirow[t]{2}{*}{ Std. dev. } & \multirow[t]{2}{*}{$N$} \\
\hline & & & & & & \\
\hline & & 59 & 303 & 914 & 695 & 145 \\
\hline & Female & 62 & 285 & 953 & 799 & 159 \\
\hline \multirow{3}{*}{$\begin{array}{l}\text { Race / population } \\
\text { group }\end{array}$} & White & 61 & 179 & 1035 & 768 & 80 \\
\hline & African & 60 & 229 & 947 & 764 & 129 \\
\hline & Coloured & 60 & 108 & 836 & 708 & 95 \\
\hline \multirow[t]{3}{*}{ Age } & $20 s$ & 56 & 237 & 880 & 783 & 116 \\
\hline & $30 s$ & 60 & 162 & 864 & 689 & 84 \\
\hline & $40 s$ & 66 & 189 & 1056 & 750 & 104 \\
\hline \multirow[t]{2}{*}{ Marital status } & Married & 65 & 156 & 1040 & 797 & 136 \\
\hline & Not married & 57 & 349 & 851 & 702 & 168 \\
\hline \multirow[t]{2}{*}{ Has children? } & Yes & 65 & 303 & 1031 & 734 & 165 \\
\hline & No & 56 & 285 & 822 & 757 & 139 \\
\hline \multirow{2}{*}{$\begin{array}{l}\text { Dependable } \\
\text { worker, actively } \\
\text { looking for work? }\end{array}$} & Yes & 61 & 289 & 935 & 857 & 150 \\
\hline & Not specified & 60 & 179 & 934 & 630 & 154 \\
\hline \multicolumn{7}{|c|}{ Characteristic of respondent } \\
\hline \multirow[t]{2}{*}{ Gender } & Male & 58 & 230 & 940 & 733 & 113 \\
\hline & Female & 63 & 358 & 930 & 734 & 195 \\
\hline \multirow{3}{*}{$\begin{array}{l}\text { Race / population } \\
\text { group }\end{array}$} & White & 64 & 139 & 1519 & 973 & 56 \\
\hline & African & 61 & 197 & 685 & 399 & 112 \\
\hline & Coloured & 59 & 234 & 913 & 750 & 136 \\
\hline \multirow[t]{3}{*}{ Age } & $20 s$ & 59 & 140 & 938 & 896 & 74 \\
\hline & $30 s$ & 59 & 139 & 980 & 673 & 68 \\
\hline & $40 s$ & 66 & 111 & 780 & 495 & 50 \\
\hline \multirow[t]{2}{*}{ Marital status } & Married & 69 & 297 & 935 & 716 & 143 \\
\hline & Not married & 62 & 291 & 934 & 781 & 161 \\
\hline \multirow[t]{2}{*}{ Has children? } & Yes & 61 & 426 & 874 & 682 & 223 \\
\hline & No & 58 & 161 & 1093 & 889 & 81 \\
\hline \multirow{2}{*}{$\begin{array}{l}\text { Occupational } \\
\text { status }\end{array}$} & Working & 60 & 272 & 1097 & 856 & 133 \\
\hline & Not working & & & & & \\
\hline Income & Rich & 62 & 123 & 1197 & 743 & 48 \\
\hline \multirow[t]{5}{*}{ Education } & $<$ grade 7 & 59 & 72 & 704 & 361 & 38 \\
\hline & Grades 7 - 9 & 60 & 132 & 763 & 562 & 83 \\
\hline & Grades $10-11$ & 62 & 131 & 792 & 615 & 73 \\
\hline & Grade 12 & 60 & 137 & 1124 & 865 & 59 \\
\hline & $>$ grade 12 & 59 & 112 & 1427 & 1000 & 54 \\
\hline \multicolumn{7}{|c|}{ Respondent-beneficiary pairing } \\
\hline \multicolumn{2}{|l|}{ White-to-white } & 66 & 41 & 1959 & 1297 & 11 \\
\hline \multicolumn{2}{|l|}{ White-to-African } & 67 & 55 & 1486 & 817 & 28 \\
\hline White-to-coloured & & 58 & 43 & 1288 & 867 & 17 \\
\hline African-to-white & & 63 & 61 & 745 & 289 & 32 \\
\hline African-to-African & & 63 & 79 & 712 & 506 & 48 \\
\hline African-to-coloure & & 58 & 57 & 591 & 273 & 32 \\
\hline Coloured-to-white & & 58 & 69 & 1014 & 646 & 37 \\
\hline Coloured-to-Africa & & 55 & 93 & 900 & 794 & 53 \\
\hline Coloured-to-colour & & 62 & 72 & 850 & 765 & 46 \\
\hline
\end{tabular}

Note: mean amount awarded is only if an award was approved, i.e. if $>0$. Data generated using vignette.do. 


\section{The Centre for Social Science Research Working Paper Series}

\section{RECENT TITLES}

Case, A. Menendez, A. Ardington, C. 2005. Health Seeking Behaviour in Northern KwaZulu-Natal. CSSR Working Paper No. 116.

Nattrass, N. 2005. An Exploratory Analysis of Cross-Country Access to Antiretroviral Treatment. CSSR Working Paper No. 117

Lam, D. Leibbrandt, M. Ranchhod, V. 2005. Labour Force Withdrawal of the Elderly in South Africa. CSSR Working Paper No. 118.

Shelmerdine, S. Relationships between adolescents and adults: The significance of narrative and context. CSSR working paper no. 119.

Brandt, R. Coping with HIV / AIDS: A case study of the psychological experiences of poor, HIV positive mothers and women caregivers on HAART. CSSR working paper no. 120.

du Toit, A. 2005. Chronic and Structural Poverty in South Africa: challenges for action and research? CSSR Working Paper no. 121.

Archer, S. 2005. The basic homework on basic income grants. CSSR Working Paper no. 122.

Magruder, J. Nattrass, N. 2005. Attrition in the Khayelitsha Panel Study (20002004). CSSR Working Paper no. 123.

Seekings with Jooste, T. Langer, M. Maughan Brown, M. 2005. Inequality and Diversity in Cape Town: An Introduction and User's Guide to the 2005 Cape Area Study. CSSR Working Paper no. 124. 


\section{The Centre for Social Science Research}

The CSSR is an umbrella organisation comprising five units:

The AIDS and Society Research Unit (ASRU) supports innovative research into the social dimensions of AIDS in South Africa. Special emphasis is placed on exploring the interface between qualitative and quantitative research. By forging creative links between academic research and outreach activities, we hope to improve our understanding of the relationship between AIDS and society and to make a difference to those living with AIDS. Focus areas include: AIDS-stigma, sexual relationships in the age of AIDS, the social and economic factors influencing disclosure (of HIV-status to others), the interface between traditional medicine and biomedicine, and the impact of providing antiretroviral treatment on individuals and households.

The Data First Resource Unit ('Data First') provides training and resources for research. Its main functions are: 1) to provide access to digital data resources and specialised published material; 2) to facilitate the collection, exchange and use of data sets on a collaborative basis; 3 ) to provide basic and advanced training in data analysis; 4) the ongoing development of a web site to disseminate data and research output.

The Democracy in Africa Research Unit (DARU) supports students and scholars who conduct systematic research in the following three areas: 1) public opinion and political culture in Africa and its role in democratisation and consolidation; 2) elections and voting in Africa; and 3) the impact of the HIV/AIDS pandemic on democratisation in Southern Africa. DARU has developed close working relationships with projects such as the Afrobarometer (a cross national survey of public opinion in fifteen African countries), the Comparative National Elections Project, and the Health Economics and AIDS Research Unit at the University of Natal.

The Social Surveys Unit (SSU) promotes critical analysis of the methodology, ethics and results of South African social science research. Our core activities include the overlapping Cape Area Study and Cape Area Panel Study. The Cape Area Study comprises a series of surveys of social, economic and political aspects of life in Cape Town. The Cape Area Panel Study is an ongoing study of 4800 young adults in Cape Town as they move from school into the worlds of work, unemployment, adulthood and parenthood.

The Southern Africa Labour and Development Research Unit (SALDRU) was established in 1975 as part of the School of Economics and joined the CSSR in 2002. In line with its historical contribution, SALDRU's researchers continue to conduct research detailing changing patterns of well-being in South Africa and assessing the impact of government policy on the poor. Current research work falls into the following research themes: post-apartheid poverty; employment and migration dynamics; family support structures in an era of rapid social change; the financial strategies of the poor; public works and public infrastructure programmes; common property resources and the poor. 